\title{
Correspondence
}

\section{Meningoradiculitis due to herpes simplex virus disclosing HIV infection}

SIR, A 37 year old Portuguese man with no significant previous illness was admitted to hospital for recent right sided sciatica associated with a vesicular eruption over the L5 dermatome. The pain had been present for five days and the eruption appeared a few hours after admission.

His symptoms were worst during the night. His rectal temperature was $37 \cdot 8^{\circ} \mathrm{C}$. No spinal signs and no signs of intervertebral disc protrusion were noted. There was cervical, axillary, and inguinal lymphadenopathy. The vesicles were distributed along the posterolateral aspect of the thigh, the lower leg, and the dorsum of the foot, suggesting a herpes virus infection responsible for a spinal neuritis. Clinical examination was otherwise normal.

A cerebrospinal fluid (CSF) analysis showed 36 lymphocytes and protein $1.35 \mathrm{~g} / \mathrm{l}$. Routine haematological and hepatorenal tests were normal.

On the eighth day herpes simplex virus antibodies (IgM) were detected by enzyme linked immunosorbent assay (ELISA) in the blood (6400) and the CSF (320); the ratio of CSF to serum titre of herpes simplex virus antibodies indicated intrathecal synthesis. On the other hand, cytomegalovirus and herpes zoster antibodies were not found in the CSF but only in the serum.

This unusual meningoradiculitis led to a search for an acquired cellular immunodeficiency. Chest radiography showed no abnormality. T4/T8 ratio was 1.31 with 2300 total lymphocytes, but the multitest was negative.

Even though the patient was married with three children and no history of intravenous drug abuse, human immuno-

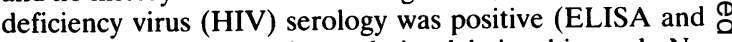
Western blot); the patient admitted being bisexual. No antibody to HIV was found in his CSF.

Complete resolution followed treatment with acyclovir $\vec{\circ}$ $8 \mathrm{mg} / \mathrm{kg}$ three times daily for 10 days. The CSF on the 22nd $\overrightarrow{\vec{A}}$ day showed six lymphocytes and protein was $0.39 \mathrm{~g} / \mathrm{l}$.

This 37 year old bisexual patient, with no previous significant medical history, developed a meningoradiculitis owing to recent herpes simplex virus infection. ${ }^{2}$ This $\underset{\nabla}{ }$ unusual infection was associated with the presence of $i r$ antibodies to HIV. ${ }^{3}$ The patient had a normal lymphocyte count and T4/T8 ratio but a negative response to multitest $\vec{D}$ suggestive of an immunosuppression. This rare neuro- 0 logical involvement is seldom encountered as an opportunistic infection. We think it suggests the possibility that the patient has an HIV infection.

Department of Rheumatology,

Hôpital Ambroise Paré,

9 avenue Charles De Gaulle,

92100 Boulogne,

Billancourt,

France

*Correspondence to Dr B Haettich.

\section{References}

1 Tenser R B. Herpes simplex and herpes zoster. Nervous system involvement. Neurol Clin 1984; 2: 215-40.

2 Ferencz A, Blinder L, Kovacs F, Kali G, Palfi A, Hollos I. Neurological infections caused by herpes simplex virus in adults. Infections 1978; 6: 211-6.

3 Cone L A, Schiffman M A. Herpes zoster and the acquired immunodeficiency syndrome. Ann Intern Med 1984; 100: 462

Ph DAHAN $\overrightarrow{0}$ B HAETTICH ${ }^{\infty}$

J M LE PARC J B PAOLAGGI

\section{Notes}

\section{XVII ${ }^{\text {th }}$ International Congress of Rheumatology-ILAR'89}

The next international congress will take place on 17-23 September 1989 in Rio de Janeiro, Brazil. Details from JZPromoções Assessoria Congressos Ltda, Rua Visconde Silva, No 52, Grupo 505 CEP. 22.271, Rio de Janeiro, RJ, Brazil.

\section{International Society for Rheumatic Therapy}

The inaugural meeting of this society will be held in
Scottsdale, Arizona, USA from 16 to 20 October 1988 , Further information from Dr Sanford H Roth, Arthritis S Center, Arizona Institutes, 3330 N 2nd Street, Suite 601, N Phoenix, AZ 85012, USA.

\section{Fourth Prague Rheumatological Symposium}

This symposium will be held in Prague from 21 to 24 June 1989. The main topic will be pharmacotherapy of rheuma- $\frac{\rho}{\Phi}$ tic diseases. Details from Czechoslovak Medical Society@ J E Purkyně, IVth Prague Rheumatological Symposium Tŕ Vítězného února 31, 12026 Praha 2, Czechoslovakia. 